\title{
LARVICIDAL ACTIVITIES OF SOME BARK AND WOOD EXTRACTS AGAINST WOOD-DAMAGING INSECTS
}

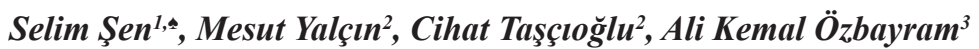

\begin{abstract}
This study investigates the larvicidal activities of plant extracts and tannins against wood-damaging insects. Scots pine (Pinus sylvestris), beech (Fagus orientalis), and poplar wood (Populus tremula) were subjected to larvae of Spondylis buprestoides (Coleoptera: Cerambycidae) by impregnating them with mimosa (Acacia mollissima), quebracho (Schinopsis lorentzii) and redpine bark (Pinus brutia) extracts. At the end of the 6-month experiment, the numbers of dead and live larvae as well as the mean mass losses of woods were determined. In terms of wood species, the lowest larva resistance was observed in Scots pine wood, while the highest larva resistance was achieved by beech wood. The lowest mass losses and the highest dead termite rates in all tree species were observed when the concentration of mimosa and quebracho extracts was $12 \%$. On the other hand, the pine bark extract showed a lower larvicide effect than the other two extracts.
\end{abstract}

Keywords: Mimosa, pine bark extract, plant extract, quebracho, Spondylis buprestoides, tannin, wood treatment.

\section{INTRODUCTION}

Wood being a biological material is readily degraded by fungi and termites (Syofuna et al. 2012) but, one of the most important causes of damage to wood materials is insects. Wood materials damaged by insects result in both technical and economic losses (Ssemaganda et al. 2011). Over the past 60 years, numerous synthetic insecticides have been developed and used. However, many countries have partially restricted or completely forbidden the use of synthetic insecticides because of their harmful effects against human health and the environmental pollution including genetic resistance of pest species, threat to wild life, motivation by weather, hazards from handling (Khatun et al. 2011, Franzen 1993, Rembold 1993, Şen et al. 2009). Thus, studies were concentrated on developing environmentally friendly wood preservations (Tascioglu et al. 2013). In this regard, plant extracts and tannins can be useful and effective against wood-damaging insects.

\footnotetext{
${ }^{1}$ Department of Forestry and Forest Products, Gumushane Vocational School, Baglarbasi Location, Gumushane, Turkey. ${ }^{2}$ Department of Industrial Forest Engineering, Duzce University, Faculty of Forestry, Konuralp Campus, Duzce, Turkey. ${ }^{3}$ Department of Forest Engineering, Duzce University, Faculty of Forestry, Konuralp Campus, Duzce, Turkey.

"Corresponding author: selimsen@gumushane.edu.tr

Received: 08.04.2016 Accepted: 10.03.2017
} 
Some extracts in woods and the other parts of the trees (bark, leaves, etc.) are tannin, flavonoid, lignan, stilbene, terpene, and terpenoid. These extracts are compounds protecting woods from biological degradation (Toshiaki 2001, Windeisen et al. 2002, Geromini et al. 2015, Fidah et al. 2016). Tannins constitute the majority of extracts. They are complex, water-soluble, and botanical polyphenols (Hagerman 2002). Tannins have a broad distribution in the plant kingdom and are found in plant tissues - bark, wood, fruit, fruit seed, leaf, stem etc. - and sap (Syofuna et al. 2012, Huş 1969). They can be categorized into two groups: hydrolysable and condensed. Especially condensed tannins constitute $90 \%$ of total commercial tannins around the world, having a production of 350000 tons/year, and they are also resistant to biodegradation (Pizzi 1983). Mimosa and quebracho extracts include high tannin content and are significant commercially condensed tannins (Haslam and Tanner 1970). In a vast number of investigations, botanical extracts and tannins have been proven to be effective against wood-damaging insects (Kirker et al. 2013, Santana et al. 2010, Zarins et al. 2009, Civelek et al. 2008, Kaygın 2007, Jembere et al. 2005, Nerg et al. 2004, Şen et al. 2002; Langenheim 1994, Halsberger et al. 1991, Gershenzon and Croteau 1991).

Insects play an important role in damaging wood materials, causing economic losses. Examples include insect types belonging to Cerambycidae, Anobidae and Lyctidae families. Another wooddamaging insect type is Spondylis buprestoides, which belongs to the Cerambycidae family from the Coleoptera class. This insect type is observed especially in Australia, Siberia, Korea, Japan, and China. It damages coniferous trees, particularly Scots pine, and other pine tree types like spruce and fir trees (Kolk and Starzyk 1996).

The objective of this study was to investigate the larvicidial effects of mimosa, quebracho and pine bark extract against Spondylis buprestoides insect larvae. Thus, it was determined that the whether or not the use of environmentally friendly tannins against insect is appropriate.

\section{MATERIALS AND METHODS}

\section{Preparation of Experimental Samples}

Wood samples used for insect test were prepared using Scots pine (Pinus sylvestris L.) (SP), beech (Fagus orientalis L.) (B), and poplar (Populus tremula L.) (P) sapwoods in $50 \times 25 \times 15 \mathrm{~mm}$ dimensions (longitudinal $x$ radial x tangential), in accordance with the TS 5564 EN 47 standard. Annual rings in the samples were made to be parallel to the broad surface, and larvae holes were perforated using drilling bits corresponding to larvae dimensions.

\section{Impregnation Process}

Before the impregnation process, solutions with different concentration levels were prepared using mimosa (Acacia mollissima) (M), quebracho (Schinopsis lorentzii) $(\mathrm{Q})$ and redpine bark (Pinus brutia) (P) powder extracts. Water was used as the solvent. Many literature studies indicated that tannin-rich extracts easily dissolve in aqueous solutions (Fennema 1996). Two concentration levels were used in all experiments: $6 \%$ and $12 \%$. Table 1 shows the $\mathrm{pH}$ values of impregnating solutions of extract species. 
Table 1. $\mathrm{pH}$ values of impregnating solutions of extract species.

\begin{tabular}{|l|c|c|}
\hline \multirow{2}{*}{\multicolumn{1}{|c|}{ Extract species }} & \multicolumn{2}{|c|}{$\mathrm{pH}$} \\
\cline { 2 - 3 } & $\% 6$ & $\% 12$ \\
\hline Acacia mollissima & 5,16 & 5,08 \\
\hline Schinopsis lorentzii & 5,49 & 5,58 \\
\hline Pinus brutia & 4,75 & 4,69 \\
\hline
\end{tabular}

Experimental samples were first dried in an oven at $60{ }^{\circ} \mathrm{C}$ for $48 \mathrm{~h}$, and then their masses were measured. To impregnate the wood samples with extracts, a cylinder applying both vacuum and pressure was used. The first step of the impregnation was to apply pre-vacuum with $600 \mathrm{~mm}-\mathrm{Hg}$ for 30 min, and later impregnating solution was sent to a boiler (Şen et al. 2009). The process was ended by applying a pressure of $8 \mathrm{kp} / \mathrm{cm}^{2}$ for $60 \mathrm{~min}$. After the impregnation process, the retention amounts of extracts were calculated using the equation in Section 2.3.

$$
\text { Retention }=\frac{G \times C}{V} \times 10 \mathrm{~kg} / \mathrm{m}^{3}
$$

$\mathrm{G}=$ The amount of solution absorbed by the sample $\left(\mathrm{m}_{\text {treated }}-\mathrm{m}_{60^{\circ} \mathrm{C}}\right)(\mathrm{g})$,

$\mathrm{m}_{60^{\circ} \mathrm{C}}=$ weight before impregnation $(\mathrm{g}), \mathrm{m}_{\text {treated }}=$ wet weight after impregnation $(\mathrm{g})$,

$\mathrm{C}=$ Solution concentration $(\%)$

$\mathrm{V}=$ The volume of the wood samples $\left(\mathrm{cm}^{3}\right)$

\section{Larva Experiments}

The insect tests were made according to the TS 5564 EN 47-1996 standards with minor modifications like insect species. This method explains criteria to evaluate the impregnated material. In all experiments, larvae belonging to the Spondylis buprestoides (Coleoptera: Cerambycidae) insect were used. All larvae were supplied from Erzurum. They were carefully collected and then weighed. Larvae having masses between 50 and $60 \mathrm{mg}$ were preserved in a humid Scots pine wood dust for subsequent use. The species of the insect was identified by the Entomology Department of the Faculty of Forestry of Duzce University. Insects belonging to the Cerambycidae family cause severe damage to wood materials (Kaygın 2007); thus, this insect species is widely used in investigations studying wood-damaging insects including this particular experiment.

Before introducing larvae into impregnated samples, they were weighed and dried, at $60{ }^{\circ} \mathrm{C}$ for $48 \mathrm{~h}\left(\mathrm{~m}_{60^{\circ} \mathrm{C}-1}\right)$. Transverse cross-sections of samples were perforated with a hole that was 1,5 times the larva diameter. Larvae were placed into their holes so that their heads could be below and subjected to larvae damage for 6 months. Climate conditions of the laboratory were arranged to be identical with the larvae's climate. Temperature values of larvae's region ranged between 25 and $30{ }^{\circ} \mathrm{C}$ during daytime and between 15 and $20^{\circ} \mathrm{C}$ at night. Therefore, temperature and humidity of the laboratory were set to be $22{ }^{\circ} \mathrm{C} \pm 2$ and $75 \pm 3 \%$, respectively.

To evaluate the damage caused by larvae, the activities of the impregnated materials on the larvae were determined each month by calculating the number of dead larvae, the number of larvae actively causing damage, and mass losses caused by larvae on impregnated and unimpregnated wood samples. All larvae were removed from the experimental samples, and larva bites inside the samples were cleaned. All samples were dried at $60{ }^{\circ} \mathrm{C}$ for $48 \mathrm{~h}$, and weighed. Mass losses were calculated using the equation below. 
Mass loss $(\%)=\left[\left(\mathrm{m}_{60^{\circ} \mathrm{C}-1}-\mathrm{m}_{60^{\circ} \mathrm{C}-2}\right) / \mathrm{m}_{60^{\circ} \mathrm{C}-1}\right] \times 100$

$\mathrm{m}_{60^{\circ} \mathrm{C}-1}=$ Dried masses $(\mathrm{g})$ of samples at $60^{\circ} \mathrm{C}$ before experiments,

$\mathrm{m}_{60^{\circ} \mathrm{C}-2}=$ Dried masses $(\mathrm{g})$ of samples at $60^{\circ} \mathrm{C}$ after experiments.

During the 6-month experiment, active larvae in each experimental sample were designated as "+", living but inactive larvae were designated as "+", and dead larvae or larvae in pupation were designated as "-".

\section{Wood Composition Analyses}

To determine from which wood constituent Spondylis buprestoides larvae are fed, chemical analyses were performed in frass and feces of larvae. These chemical analyses are alpha-cellulose (Wise and Karl 1962), holocellulose (Wise and Karl 1962), and extractive material (T 204 om, 1997) and lignin (T $222 \mathrm{om}, 1998$ ) analysis. And the sugar analysis of Scots pine wood frass caused by larva bites were performed with HPLC (High-Performance Liquid Chromatography) at the Duzce University Forest Faculty.

\section{RESULTS AND DISCUSSION}

\section{Retention}

For determining the impregnation amounts of wood samples having different concentration levels, their retention amounts were calculated, as shown in Table 2. When eighteen mean values including wood species (WS), extract species (ES) and concentration (C) factors were compared, the best result was achieved by poplar and Scots pine wood samples impregnated with quebracho extract at a $12 \%$ concentration level. Their retention amounts were found to be 91,5 and $81,3 \mathrm{~kg} / \mathrm{m}^{3}$ respectively. The majority of the studies indicate that retention values can vary depending on wood and extract species (Şen 2001, Tırak 2006).

Table 2. Mean retention values of wood samples impregnated with extractive materials at different concentration levels (The values in the parentheses indicate standard deviations).

\begin{tabular}{|c|c|c|c|c|c|c|}
\hline & \multicolumn{9}{|c|}{ Retention $\left(\mathrm{kg} / \mathrm{m}^{3}\right)^{*}$} \\
\hline ES/C & \multicolumn{2}{|c|}{ Scots pine } & \multicolumn{2}{|c|}{ Beech } & \multicolumn{2}{c|}{ Poplar } \\
\hline M 6\% & $26,8(1,8)$ & $\boldsymbol{b}$ & $25,5(6,3)$ & $\boldsymbol{b}$ & $22,0(8,3)$ & $\boldsymbol{a} \boldsymbol{b}$ \\
\hline $\mathrm{M} \mathrm{12 \%}$ & $72,6(6,5)$ & $\boldsymbol{c d}$ & $73,2(0,6)$ & $\boldsymbol{c d}$ & $73,4(9,6)$ & $\boldsymbol{c} \boldsymbol{d}$ \\
\hline $\mathrm{Q} 6 \%$ & $15,9(2,3)$ & $\boldsymbol{a}$ & $25,8(2,0)$ & $\boldsymbol{b}$ & $25,3(4,3)$ & $\boldsymbol{b}$ \\
\hline $\mathrm{Q} 12 \%$ & $81,3(2,9)$ & $\boldsymbol{e}$ & $69,9(2,1)$ & $\boldsymbol{c d}$ & $91,5(1,3)$ & $\boldsymbol{f}$ \\
\hline P 6\% & $21,52,6)$ & $\boldsymbol{a b}$ & $23,4(0,6)$ & $\boldsymbol{b}$ & $21,4(7,0)$ & $\boldsymbol{a} \boldsymbol{b}$ \\
\hline P 12\% & $72,1(0,2)$ & $\boldsymbol{c d}$ & $66,8(1,4)$ & $\boldsymbol{c}$ & $74,5(8,1)$ & $\boldsymbol{d}$ \\
\hline
\end{tabular}

*The difference between mean values indicated by same letters and column are statistically insignificant $(\mathrm{p}<0,05)$. (ES: Extract species, C: concentration, M: Acacia mollissima, Q:Schinopsis lorentzii, P: Pinus brutia) 


\section{Mass Losses}

Mean mass losses obtained from the control samples of unimpregnated Scots pine, beech and poplar wood species were $47,2 \% ; 25,2 \%$ and $30,6 \%$ respectively. Results indicated that Scots pine wood samples had the highest damage, while beech and poplar wood species had lower mass losses. Thus, it can be said that beech and poplar trees in the raw condition were more resistant than Scots pine.

Mean mass losses in the Scots pine wood samples impregnated with extracts at different concentration levels and monthly larva examination results are shown in Table 3. Scots pine wood samples impregnated with mimosa at a $12 \%$ concentration level had an efficient resistance against larvae of $S$. buprestoides, and a very low mass loss $(14,6 \%)$ was observed. Mean decreasing mass loss rete of Scots pine wood samples treated with mimosa tannin compared to untreated control samples were calculated as $69,1 \%$. The difference between the $6 \%$ concentration level of mimosa and quebracho extracts and mean mass losses of Scots pine control samples was found to be statistically significant $(p<0,05)$. However, the difference between mean mass losses of pine bark extracts at two concentration levels and those of control samples was statistically insignificant $(\mathrm{p}<0,05)$.

When monthly examination results of larvae were evaluated, it was observed that the majority of larvae in the Scots pine control samples were still alive until the end of the sixth month and they actively caused damage to the samples. In addition, larvae began to go into the pupation beginning from the second month. Larvae activities in the Scots pine samples impregnated with mimosa and quebracho at a $6 \%$ concentration level continued until the end of the fourth month. On the other hand, larvae in the pine bark extract at a $6 \%$ concentration level caused damage until the end of the fifth month.

When concentration levels of mimosa and quebracho extracts were increased up to $12 \%$, it was determined that all larvae died at the end of the second month. For the pine bark extract at a $12 \%$ concentration level, some larvae could remain alive until the end of the fifth month. The study conducted by Şen (2001) indicated that death rates in the Scots pine wood samples impregnated with the gallnut powder (Quercus infectoria), sumac leaf (Rhus coriariae) extract and valonia (Quercus macrolepis) extracts were $84 \%, 80 \%$, and $76 \%$, respectively. However, in the same study they also observed a very low larvae death rate (28\%) in the Scots pine wood samples impregnated with the pine bark extract.

When concentration levels of all extracts in this study were increased from $6 \%$ to $12 \%$, mass losses occurred at a certain level. Results showed that the increase in the concentration levels of all extracts affected mass losses caused by larvae, which made wood samples more resistant against larvae. Civelek and Colak (2008) found similar results, and they stated that Calabrian pine wood samples impregnated with different extracts were effective on larvae. In another study, Scots pine wood samples impregnated with beech wood extracts had a preventive effect against larvaes (Haslberger and Fergel 1991).

Table 3. Mean mass losses of S. buprestoides larvae in the Scots pine wood samples and monthly larva evaluation results.

\begin{tabular}{|c|c|c|c|c|c|c|c|c|c|}
\hline \multirow{3}{*}{$\begin{array}{l}\text { Extract } \\
\text { Species }\end{array}$} & \multirow{3}{*}{$\begin{array}{c}\text { Concentration }(\%) \\
\text { Control } * *\end{array}$} & \multirow{2}{*}{\multicolumn{2}{|c|}{$\begin{array}{c}\text { Mass loss } \\
(\%)^{*}\end{array}$}} & \multicolumn{6}{|c|}{ Monthly larva evaluation*** } \\
\hline & & & & \multirow{2}{*}{$\begin{array}{c}1 \\
++++\end{array}$} & \multirow{2}{*}{$\begin{array}{c}2 \\
+++\end{array}$} & \multirow{2}{*}{$\begin{array}{c}3 \\
++\end{array}$} & \multirow{2}{*}{$\begin{array}{c}4 \\
+++\end{array}$} & \multirow{2}{*}{$\begin{array}{c}5 \\
++\end{array}$} & \multirow{2}{*}{$\begin{array}{l}6 \\
+\end{array}$} \\
\hline & & $47,2(2,6)$ & $e$ & & & & & & \\
\hline \multirow{2}{*}{ Mimosa } & 6 & $38,3(3,7)$ & $d$ & +++ & +++ & ++ & + & - & - \\
\hline & 12 & $14,6(13,1)$ & $a$ & ++ & + & - & - & - & - \\
\hline \multirow{2}{*}{ Quebracho } & 6 & $31,1(1,8)$ & $c$ & +++ & ++ & ++ & ++ & - & - \\
\hline & 12 & $20,7(2,0)$ & $b$ & +++ & ++ & & - & - & - \\
\hline \multirow{2}{*}{ Pine bark } & 6 & $47,5(2,6)$ & $e$ & +++ & +++ & +++ & ++ & + & - \\
\hline & 12 & $31,5(4,4)$ & $c$ & ++++ & ++ & ++ & & - & - \\
\hline
\end{tabular}

* The difference between mean values indicated by same letters is statistically insignificant $(\mathrm{p}<0,05)$

**Data of the control group was subjected to variance analysis for each extract type

*** Each plus indicates one larva. Bold pluses $(+)$ are active-alive; unbold pluses $(+)$ are passive-alive; minus $(-)$ is dead larvae or larvae in the pupation 
Mean mass losses of beech wood samples and monthly examination results are shown in Table 4 results show that beech wood samples impregnated with mimosa and quebracho extracts at $12 \%$ concentration level can be effective against $S$. buprestoides larvae. Mass losses of these beech wood samples impregnated with mimosa and quebracho extracts were $0,9 \%$ and $1,8 \%$ respectively. Mean decreasing mass loss rete of beech wood samples treated with mimosa $(12 \%)$ and quebracho $(12 \%)$ extracts compared to untreated control samples were calculated as 96,4 and $92,8 \%$ respectively (Figure $1)$. The difference between mean values was statistically insignificant $(\mathrm{p}<0,05)$. In addition, mass losses of both extracts at a $6 \%$ concentration level were lower than control samples, and the difference between them was statistically significant. While there was a statistically significant difference between mass losses of beech wood samples impregnated with pine bark extracts at $6 \%$ and $12 \%$ concentration levels, pine bark extracts could not provide an effective resistance against larvae at both concentration levels as much as the mimosa and quebracho extracts could.

Table 4. Mean mass losses of S. buprestoides larvae in the beech wood samples and monthly larva evaluation results.

\begin{tabular}{|c|c|c|c|c|c|c|c|c|c|}
\hline \multirow{3}{*}{ ES } & \multirow{2}{*}{$\mathrm{C}(\%)$} & \multirow{2}{*}{\multicolumn{2}{|c|}{ Mass loss $(\%)^{*}$}} & \multicolumn{6}{|c|}{ Monthly larva evaluation $* * *$} \\
\hline & & & & 1 & 2 & 3 & 4 & 5 & 6 \\
\hline & Control** & $25,1(2,7)$ & $d$ & +++ & +++ & ++ & ++ & - & - \\
\hline \multirow{2}{*}{ M } & 6 & $12,0(2,4)$ & $b$ & +++ & ++ & - & - & - & - \\
\hline & 12 & $0,9(0,7)$ & $a$ & + & - & - & - & - & - \\
\hline \multirow{2}{*}{ Q } & 6 & $12,5(1,5)$ & $\boldsymbol{b}$ & +++ & ++ & + & - & - & - \\
\hline & 12 & $1,8(1,5)$ & $a$ & ++ & - & - & - & - & - \\
\hline \multirow{2}{*}{$\mathrm{P}$} & 6 & $22,9(3,1)$ & $d$ & +++ & +++ & ++ & + & - & - \\
\hline & 12 & $18,4(1,9)$ & $c$ & ++ & ++ & + & - & - & - \\
\hline
\end{tabular}

(ES: Extract species, C: concentration, M: Acacia mollissima, Q:Schinopsis lorentzii, P: Pinus brutia)

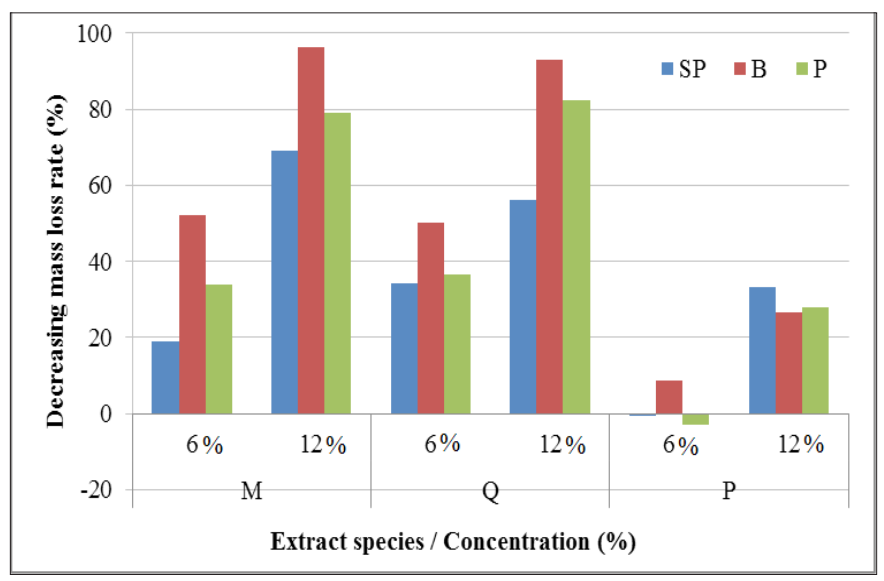

Figure 1. Decreasing mass loss rate of treated wood samples compared to untreated control samples. (M: Acacia mollissima, Q:Schinopsis lorentzii, P: Pinus brutia).

(SP: Scots Pine wood samples, B:Beech wood samples, P:Poplar wood samples) 
Monthly evaluation results showed that while larvae in the beech control samples caused damage until the end of the third month, death rates increased beginning from the fifth month because of the larvae pupation. Live larva could not be observed after the end of the fifth month. Beginning from the third month, damage caused by larvae stopped at a $6 \%$ concentration level of mimosa and quebracho extracts. It was observed in the pine bark extract that some larvae could remain alive until the beginning of the fourth month, and live larvae caused damage. When the concentration levels of mimosa and quebracho extracts were increased to $12 \%$, the number of live larvae was considerably decreased compared to control beech wood samples, and from the end of the first month, no live larva was observed in the wood samples impregnated with both extracts. No significant difference was determined in the amounts of the frass in both impregnated and unimpregnated control samples, obtained as a result of larva damage.

Mean mass losses in the poplar wood samples and monthly larva evaluation results are shown in Table 5. Results indicated that mass losses of the mimosa, quebracho and pine bark extracts at a $12 \%$ concentration level decreased from $30,6 \%$ to $6,4 \% ; 5,4 \%$ and $22,1 \%$ respectively. When their concentration levels decreased to $6 \%$, considerable increases in mass losses were observed.

Table 5. Mean mass losses of S. buprestoides larvae in the poplar wood samples and monthly larva evaluation results.

\begin{tabular}{|c|c|c|c|c|c|c|c|c|c|}
\hline \multirow{3}{*}{$\begin{array}{l}\text { Extract } \\
\text { Species }\end{array}$} & \multirow{3}{*}{$\begin{array}{c}\text { Concentration } \\
(\%)\end{array}$} & \multirow{2}{*}{\multicolumn{2}{|c|}{ Mass loss $(\%)^{*}$}} & \multicolumn{6}{|c|}{ Monthly larva evaluation $* * *$} \\
\hline & & & & \multirow{2}{*}{$\frac{1}{+++}$} & \multirow{2}{*}{$\begin{array}{c}2 \\
+++\end{array}$} & \multirow{2}{*}{$\begin{array}{c}3 \\
+++\end{array}$} & \multirow{2}{*}{$\begin{array}{c}4 \\
++\end{array}$} & \multirow{2}{*}{$\begin{array}{l}5 \\
+ \\
\end{array}$} & \multirow{2}{*}{$\begin{array}{l}6 \\
- \\
\end{array}$} \\
\hline & & $30,6(6,7)$ & $c$ & & & & & & \\
\hline \multirow{2}{*}{ Mimosa } & 6 & $20,2(1,3)$ & $b$ & +++ & ++ & + & - & - & - \\
\hline & 12 & $6,4(1,5)$ & $a$ & + & + & - & - & - & - \\
\hline \multirow{2}{*}{ Quebracho } & 6 & $19,4(2,6)$ & $b$ & ++ & ++ & ++ & + & - & - \\
\hline & 12 & $5,4(1,4)$ & $a$ & ++ & + & - & - & - & - \\
\hline \multirow{2}{*}{ Pine bark } & 6 & $31,5(3,1)$ & $c$ & +++ & ++ & ++ & + & - & - \\
\hline & 12 & $22,1(2,4)$ & $b$ & ++ & ++ & + & & - & \\
\hline
\end{tabular}

Although feces and frass caused by the larvae were removed at the beginning of the experiment, they were subsequently identified in the tunnels bored within wood samples. Moreover, the amounts of frass differed in the impregnated and unimpregnated samples. The amounts of frass in Scots pine and poplar wood species increased with increasing concentration levels of extracts. Such an increase was not observed in beech wood samples.

Results showed that as a result of the increase in concentration (from 6\% to $12 \%$ ) in three wood samples impregnated with mimosa and quebracho extracts, a linear increase in larvae death rates was determined across the positive direction. In addition, a negative-directional relationship was determined between the mass losses and death rates of larvae. Similar results were found in some studies using botanical extracts (Nerg et al. 2004).

An inhibiting effect of phenolic compounds against the growth of insect larvae was determined in numerous investigations (Haslam 1988, Scalbert 1991, Fettköther et al. 2000). High larva resistance of mimosa and quebracho extracts is considered to be due to their compositions. Many compounds having insecticide features were determined by high-performance liquid chromatography (HPLC) analyses in mimosa, quebracho and pine bark extracts (Taşcioğlu et al. 2012). It was determined by some studies (Guerra et al. 1990, Isman and Duffy 1982, Simmonds 2003) that catechol and rutin found in mimosa 
and quebracho extracts were effective compounds against insects.

\section{Composition Analyses of Scots pine frass caused by Larva Bites}

Entomological experiments conducted for determining insecticide characteristics of extracts against $S$. buprestoides larvae indicated that Scots pine wood was the most affected wood type by larvae. Chemical analyses were conducted to determine the wood compositions of Scots pine samples, as shown in Table 6. Frass caused by larvae and Scots pine wood control samples were compared. Holocellulose amount of frass were lower than that of control samples, while the amounts of extractive materials, alpha-cellulose and lignin increased in frass. Results indicated that the larvae of $S$. buprestoides caused the highest damage to holocellulose.

Table 6. Compositions of Scots pine frass.

\begin{tabular}{|l|c|c|}
\hline Wood components & $\begin{array}{c}\text { Undigested } \\
\text { Control (\%) }\end{array}$ & $\begin{array}{c}\text { Digested } \\
\text { frass (\%) }\end{array}$ \\
\hline Extractives & $2,95 \pm 0,43$ & $4,86 \pm 0,29$ \\
\hline Holocellulose & $76,07 \pm 0,37$ & $70,71 \pm 1,09$ \\
\hline Alpha-cellulose & $60,87 \pm 0,46$ & $65,85 \pm 0,30$ \\
\hline Lignin & $23,93 \pm 0,37$ & $29,29 \pm 1,09$ \\
\hline
\end{tabular}

Sugar analyses were conducted to determine holocellulose compositions in the Scots pine wood samples. Table 7 indicated that the highest mass loss in holocelluloses $(29,3 \%)$ was observed in the glucose sugar. There were also observed mass losses in the mannose sugar $(20,7 \%)$ and in the arabinose sugar $(7,1 \%)$.

Table 7. Sugar analysis results of Scots pine wood frass caused by larva bites.

\begin{tabular}{|l|c|c|c|}
\hline \multicolumn{1}{|c|}{ Sugars } & $\begin{array}{c}\text { Undigested } \\
\text { Control } \mathbf{( g / L )}\end{array}$ & $\begin{array}{c}\text { Digested } \\
\text { frass (g/L) }\end{array}$ & Loss (\%) \\
\hline Glucose & $0,14 \pm 0,011$ & $0,09 \pm 0,037$ & 29,32 \\
\hline Mannose & $0,08 \pm 0,013$ & $0,06 \pm 0,004$ & 20,70 \\
\hline Arabinose & $0,041 \pm 0,024$ & $0,04 \pm 0,021$ & 7,06 \\
\hline
\end{tabular}

GC-MS analysis results of three extracts are shown in Table 8. Results indicated that many fatty acids having an insecticide characteristic were determined. Especially caprylic and linoleic fatty acids were considered to be efficient factors on the activities of extracts against larvae (Kio 1990, Ralston et al. 2012). 
Table 8. GC-MS results of extractive components dissolved in methanol

\begin{tabular}{|c|c|c|c|}
\hline Extracts & Compounds & Rt (min) & $\%$ Area \\
\hline \multirow{6}{*}{ Mimosa } & Phenethyl alcohol & 8,79 & 1,15 \\
\hline & Caprylic acid & 11,92 & 1,90 \\
\hline & $\begin{array}{l}\text { 1-pyridin-2-oen(1-(2-(1,3-Benzodioxol-5-yl)ethyl)- } \\
1,3,4 \mathrm{~A}, 5,6 \text {-hexa) }\end{array}$ & 13,98 & 0,33 \\
\hline & Linoleic acid & 16,21 & 0,065 \\
\hline & Nonanoic acid,9-oxo, methyl ester & 18,01 & 0,23 \\
\hline & Behenic acid ME & 19,83 & 0,77 \\
\hline \multirow{14}{*}{ Quebracho } & Ethanthiol,2(Diethylboryloxy) & 6,85 & 22,50 \\
\hline & Phenethyl alcohol & 8,79 & 10,10 \\
\hline & Acetic acid,((phenymethoxy)ımıno)-trimethylsil ester & 7,34 & 5,70 \\
\hline & Caprylic acid & 10,19 & 2,36 \\
\hline & 2-Heptenal,(E)- & 10,64 & 0,52 \\
\hline & Propane ,2-Flupro-2-methyl & 11,01 & 0,59 \\
\hline & $\begin{array}{l}\text { 1-pyrindin-2-oen(1-(2-(1,3-benzodioxol-5-1)ethyl)- } \\
1,3,4 \mathrm{~A}, 5,6 \text {-hexahydro })\end{array}$ & 13,97 & 3,49 \\
\hline & 3-methyl-2(2-oxopropyl)furan & 14,87 & 0,83 \\
\hline & Lauric acid & 15,08 & 8,30 \\
\hline & Hyroquinone & 15,85 & 2,37 \\
\hline & Linoleik acid & 16,19 & 3,12 \\
\hline & Heptacosanoic acid,2,5-methyl,methyl ester & 16,52 & 0,37 \\
\hline & Nonanoic acid, 9-oxo,methyl ester & 18,01 & 0,30 \\
\hline & Stearyl alcohol & 20,86 & 0,90 \\
\hline \multirow{4}{*}{ Pine bark } & 3-methyl-2-(2-oxopropyl)furan & 13,29 & 0,11 \\
\hline & Capylic acid & 13,56 & 1,20 \\
\hline & 1-benzoxepin,2,3,4,5-tetrahydro & 13,98 & 0,20 \\
\hline & Linoleic acid & 16,82 & 0,28 \\
\hline
\end{tabular}

Rt: Retensiyon time (minute),

\section{CONCLUSIONS}

When control samples of wood species were compared, it was observed that beech and poplar wood samples were more resistant than Scots pine samples. A 6-month experiment series conducted on larvae showed that the number of dead larvae in beech and poplar trees was higher than that in the Scots pine tree. When the concentration level was $12 \%$ in the Scots pine wood samples impregnated with mimosa and quebracho extracts, mean mass losses decreased by $2 / 3$. Therefore, Scots pine wood samples impregnated with mimosa and quebracho at a $12 \%$ concentration level obtained significant resistance against larvae. Correspondingly, an increase in death rates of larvae was observed from the beginning of the first month. There were some similarities between the mass losses and larvae death rates of beech and poplar wood samples. It was observed that mass losses in poplar wood samples impregnated with pine bark extract at a $12 \%$ concentration level were lower than control samples by the ratio of $2 / 3$. As a result of the increase in concentration level, the resistance against larvae increased at a certain level in three wood samples impregnated with pine bark extract. However, these increases in resistance were not as high as those caused by mimosa and quebracho extracts. 


\section{REFERENCES}

Civelek, H.S.; Çolak, A.M. 2008. Effects of some plant extracts and bensultap on Trichoferus griseus (Coleoptera: Cerambycidae). World Journal of Agricultural Sciences 4: 721-725.

Fennema, O.R. 1996. Food Chemistry. ( ${ }^{\text {rd }}$ ed.), New York: Marcel Dekker, 780-782.

Fettköther, R.; Reddy, G.V.P.; Noldt, U.; Dettner, K. 2000. Effect of host and larval frass volatiles on behavioural response of the old house borer, Hylotrupes bajulus (L.) Coleoptera: Cerambycidae, in a wind tunnel bioassay. Chemoecology 10: 1-10.

Fidah, A.; Salh, N.; Rahouti, M.; Kabouchi, B.; Ziani, M.; Aberchane, M.; Famiri, A. 2016. Natural durability of Cedrus atlantica wood related to the bioactivity of its essential oil against wood decaying fungi. Maderas-Cienc Tecnol 18: 567-576.

Franzen, H. 1993. Need for development of new strategies for locust control. In: New strategies for locust control. Ed: Rembold, H. ATSAF. Bonn. 89, 9-13.

Geromini, K.V.N.; Roratto, F.B.; Ferreira, F.G.; Camilotti, J.; Vidigal, T.M.A.; Valle, J.S.; Colauto, N.B.; Linde, G.A. 2015. Fungicidal effect of Lippia alba essential oil on a white-rot fungus. Maderas-Cienc Tecnol 17: 29-38.

Gershenzon, J.; Croteau, R. 1991. Terpenoids. In G. A. Rosenthal and M. R. Berenbaum (eds.). Herbivores: Their Interactions with Secondary Plant Metabolites, $2^{\text {nd }}$ ed. Academic Press, Orlando, Florida, 165-219.

Guerra, D.J.; Cothren, J.T.; Phillips, J.R. 1990. Influence of selected phenolic compounds on development of bollworm (Lepidoptera: Noctuidae). Journal of Economic Entomology 83: 2115-2118.

Hagerman, A.E. 2002. Tannin Chemistry. Department of chemistry and biochemistry, Miami University, USA.

Haslam, E. 1988. Plant polyphenols (syn. vegetable tannins) and chemical defence a reappraisal. Journal of Chemical Ecology 14: 1789-1805. 2309.

Haslam, E.; Tanner, R. 1970. Spectrophotometric assay of tannase. Phytochemistry 90: 2305-

Hus, S. 1969. Orman Mahsulleri Kimyası, IU Orman Fakültesi, IÜ Yayın No:1451, of Yayın No:150, Istanbul 195.

Haslberger, H.; Fengel, D. 1991. Larvae development of the house longhorn beetle in pinewood treated with different beechwood extracts. Holz als Roh-und Werkstoff 49: 229-234.

Isman, M.B.; Duffey, S.S. 1982. Toxicity of tomato phenolic compounds to the fruitworm, Heliothis zea. Entomologia Experimentalis et Applicata 31: 370-376.

Jembere, B.; Getahun, D.; Negash, M.; Sevoum, E. 2005. Toxicity of Birbira (Milletia ferruginea) seed crude extracts to some insect pests as compared to other botanical and synthetic insecticides. $11^{\text {th }}$ NAPRECA (Natural Products and Drug Delivery) Symposium Book of Proceeding, Astanarivo, Madagaskar, 88-96.

Kaygin, A.T. 2007. Industrial Wood Pests, Nobel Publication No: 1082, 1. Edition, Science and Biology Publications No. 31, Ankara. 
Khatun, M.; Talukder, D.; Hye, A. 2011. Insecticidal activity of Acacia catechu bark extract against four stored product pests. Int J Sustain Crop Prod 6(1):1-5.

Kio, N.D.P.1990. Insecticidal activity of fatty acid constituents of fixed vegetable oils against Callosobruchus maculatus (F.) on cowpea. Pesticide Science 30 (3) 295-302.

Kirker, G.T.; Blodgett, A.B.; Arango, R.A.; Lebow, P.K.; Clausen, C.A. 2013. The role of extractives in naturally durable wood species International Biodeterioration \& Biodegradation 82: 53-58.

Kolk, A.; Starzyk, J.R. 1996. The Atlas of Forest Insect Pests. The Polish Forest Research Institute, Multico Warszawa.

Langenheim, J. H. 1994. Higher plant terpenoids: a phytocentric overview of their ecological roles. Journal of Chemical Ecology 20: 1223-1280.

Nerg, A.M.; Hejari, J.; Noldt, U.; Viitanen, H.; Vuorinen, M.; Kainulainen, P.; Holopainen, J.K. 2004. Significance of wood terpenoids in the resistance of scots pine provenances against the old house borer, Hylotrupes bajulus, and brown-rot fungus, Coniophora puteana. Journal of Chemical Ecology 30:125-141.

Pizzi, A. 1983. Wood adhesives-chemistry and technology. New York, NY: Marcel Dekker Inc.

Ralston, A. W., Barrett J.P., Hopkins E.W. The insecticidal properties of some fatty acid derivates. Journal of Oil and Fat Industries, 8 (1) (2012) 11-13.

Rembold, H. 1984. Secondary plant compounds in insect control with special reference to azadirachtins. Advances in Invertebrate Reproduction 3: 481-491.

Santana, A.L.B.D.; Maranhão, C.A.; Santos, J.C.; Cunha, F.M.; Conceição, G.M.; Bieber, L.W.; Nascimento, M.S. 2010. Antitermitic activity of extractives from three Brazilian hardwoods against Nasutitermes corniger. International Biodeterioration \& Biodegradation 64: 7-12.

Scalbert, A. 1991. Antimicrobial properties of tannin. Phytochemistry 30: 3875-3883.

Simmonds, M.S. 2003. Flavonoid-insect interactions: Recent advances in our knowledge. Phytochemistry 64: 21-30.

Ssemaganda, I.E.; Mugabi, P.; Tumwebaze, S.B. 2011. Effectiveness of selected preservatives in protecting ugandan grown Eucalyptus grandis wood against termite attack. Maderas-Cienc Tecnol 13(2): 135-142.

Syofuna, A.; Banana, A.Y.; Nakabonge, G. 2012. Efficiency of natural wood extractives as wood preservatives against termite attack. Maderas-Cienc Tecnol 14(2): 155-163.

Şen, S. 2001. Determination of effetcs of some plant phenols on wood protection. $\mathrm{PhD}$ thesis, University of Karaelmas, Institute of Science, Zonguldak, Turkey, pp: 295.

Şen, S.; Hafızoğlu, H.; Kanat, M. 2002. Investigation of wood preservative activities of some plant extracts and tannins as insecticide. KSU Journal of Science and Engineering 5: 86-98. 
Şen, S.; Tascioglu, C.; Tirak, K. 2009. Fixation, leachability, and decay resistance of wood treated with some commercial extracts and wood preservative salts. International Biodeterioration \& Biodegradation 63: 135-141.

Tascioglu, C.; Yalcin, M.; Şen, S.; Akcay, C. 2013. Antifungal properties of some plant extracts used as wood preservatives. International Biodeterioration \& Biodegradation 85: 23-28.

Taşçıŏlu, C.; Yalçın, M.; Franco, T.; Sivrikaya, H. 2012. Termiticidal properties of some wood and bark extracts used as wood preservatives. BioResources 7: 2960-2969.

Tirak K. 2006. Increasing fixation properties of plant extractives and tannins which have natural wood preservation properties, Master's thesis, Abant Izzet Baysal University, Institute of Science, Turkey, pp:166.

Turkish Standards Institution. TS. 1966. Wood preservatives-Determination of the toxic values against larvae of Hylotrupes bajulus (linnaeus) (Laboratory Method), TS 5564 EN 47. Ankara, Turkey.

TAPPI Standards. 1997. Solvent Extractives of Wood and Pulp. T 204 cm-1997.

TAPPI Standards. 1998. Acid-Insoluble Lignin in Wood and Pulp. T 222 om-1998

Toshiaki, U. 2001. Chemistry of Extractives. In: Wood and cellulosic chemistry, Ed Marcel Dekker, Inc. New York, pp.213-241.

Windeisen, E.; Wegener, G.; Lesnino, G.; Schumacher, P. 2002. Investigation of the correlation between extractives content and natural durability in 20 cultivated larch trees. Holz als Roh-Werkstoff 60: $373-374$.

Wise, E.L.; Karl, H.L. 1962. Cellulose and Hemicellulose in Pulp and Paper Science and Technology. vol:1, Edited By C. Earl Libby, Mc Graw Hill Book Co., New York.

Zarins, I.; Daugavietis, M.; Halimona, J. 2009. Biological activity of plant extracts and their application as ecologically harmless biopesticide. Scientific works of the Lithuanian Institute of Horticulture and Lithuanian University of Agriculture 28, 269-280. 